\title{
Use of lookout watches over forest to estimate detection, dispersion and density of hornbills, Great Argus and diurnal raptors at Bala forest, Thailand, compared with results from in-forest line transects and spot maps
}

\author{
ALAN KEMP, MEG KEMP and SIRIPORN THONG-AREE
}

\section{Summary}

We estimated detection, dispersion and density of 1o hornbill, one pheasant and nine diurnal raptor species at Bala forest, southern Thailand, throughout 2004. We conducted 620 1-h lookout watches over the forest canopy from 14 elevated locations along $13.1 \mathrm{~km}$ of paved road through Bala, during which we recorded all detections and movements of target species. For a further $619 \mathrm{~h}$, we also recorded all in-forest detections of target species during excursions along and adjacent to the road. Our records covered all months of the year and hours of the day, enabling us to estimate seasonal and diurnal patterns of detection for each target species. We found significant seasonal and diurnal variation for all commoner species in rates of overall detection, visual versus aural detection, and vociferousness. We related most monthly variation to the timing of nesting and most hourly variation to aspects of the behavioural ecology of each species. We used three techniques to estimate dispersion and density for each species, two from lookouts based on our counts of individuals or breeding units per unit area observed, and one from spot maps of core breeding units within $500 \mathrm{~m}$ of the road. Differences in our estimates of density varied within and between species, but were mostly lowest for the mean number of individuals detected from lookouts and highest for the maximum of breeding units, whether from lookout detections or core area counts from spot maps. These ranges of densities and their variance indicate upper and lower estimates for each species, and the differences between them and other survey techniques were explicable partly by the behavioural ecology of each species or apparent changes in density. Our density estimates never exceeded the highest comparative estimates for target species or near relatives in other forest habitats, although few were available for diurnal raptors. We suggest that 1-h lookout watches over forest, where feasible, offer alternative and efficient estimates of detection, dispersion and density to conventional distance-sampling techniques conducted from within forest. They will achieve optimum accuracy when conducted during the most detectable periods for target species, particularly for obvious and sparsely dispersed bird species.

\section{Introduction}

The detection, dispersion and density of organisms are important aspects in studies of their population ecology but these are difficult to estimate in tropical rainforest, especially at the scale of such mobile low-density species as large birds. Even though such organisms often play keystone and/or flagship roles in forest ecology and/or conservation, one usually detects only a few individuals per survey, sample sizes for analysis are small, confidence intervals are low and 
detections are sensitive to temporal variation in species-specific visibility and audibility (Pomeroy and Dranzoa 1997, Wells 1999, Gale and Thongaree 2006, Kinnaird and O'Brien 2007). Yet the probability of detection and proportion of the population detected are essential components for reliable estimates of population size and dynamics (Thompson 2002, Diefenbach et al. 2007).

The largest species of birds living within Asian rainforests are hornbills, pheasants, raptors and owls (Wells 1999). There have been various reports of their detection, dispersion and density, from anecdotal to quantitative, but differences in technique and accuracy hinder comparison between studies and species (e.g. Kinnaird et al. 1996, Wells 1999, Kinnaird and O'Brien 2007). Most quantitative assessments, including at Bala, have involved some form of distance sampling conducted from within forest, usually line transects (Gale and Thong-aree 2006) or, less frequently, point counts (Marsden 1999, Marsden and Pilgrim 2003, Patanavibool et al. 2007).

In our study, we detected large birds primarily by watching and listening over the canopy of a rainforest in southern Thailand. A paved road through the forest ensured year-round access to a series of lookout points over the forest, and to the road and trails on either side where we could also move about within the forest. By recording detections and movements of target species and the time spent at lookouts or within forest, we amassed detection data per unit time that covered all months of the year and hours of the day.

For each lookout point and target species, within a prescribed area of visibility and audibility, we also determined the locations and numbers of individuals detected per unit time and so estimated their dispersion and density. For hornbills, we included all species surveyed 2-3 years previously by line transect techniques within the same area of forest (Rhinoceros Buceros rhinoceros, Great B. bicornis, Helmeted Rhinoplax vigil, Wreathed Aceros undulatus, Wrinkled A. corrugatus, Plainpouched A. subruficollis, White-crowned A. comatus, Bushy-crested Anorrhinus galeritus, Oriental Pied Anthraceocers albirostris and Black Hornbills A. malayanus; Thong-aree 2004, Gale and Thong-aree 2006). Great Argus Argusianus argus was also surveyed by these line transects, and by spot maps (Gale and Thong-aree unpubl. data). We also included resident diurnal raptors in our lookout watches since no previous information had been collected (Oriental Honey-buzzard Pernis ptilorhynchus, Bat Hawk Macheiramphus alcinus, Lesser Fish-eagle Ichthyophaga humilis, Crested Serpent-eagle Spilornis cheela, Black Eagle Ictinaetus malayensis and Rufous-bellied Eagle Lophotriorchis kienerii, Changeable Nisaetus cirrhatus and Blyth's Hawk-eagles N. alboniger, and Black-thighed Falconet Microhierax fringillarius). Our nocturnal surveys along the same road for owls and frogmouths are already published (Kemp et al. 2009).

\section{Methods}

\section{Study area}

The Bala section of Hala-Bala Wildlife Sanctuary is a mountainous $111.5 \mathrm{~km}^{2}$ area of tropical rainforest, at altitudes of 50-960 $\mathrm{m}$ asl, and surrounded by secondary forest and agriculture (Figure 1). Bala was selectively logged, mainly during the 1970s, then declared a Wildlife Sanctuary in 1997. The mean annual rainfall of $3.5 \mathrm{~m}$ has eroded the mountains into a series of sharp ridges and deep valleys, with most perennial streams draining south into the Ko-lok River along the Thai-Malaysian border. Bala falls within the northern limits of the Sundaic faunal and Malesian floral regions (Wells 1999, Niyomtham 2000, Thong-aree 2004).

We conducted our 2004 study along $13.1 \mathrm{~km}$ of paved road, constructed during 1987-92, that bisects Bala from east to west, and is marked off at $0.5 \mathrm{~km}$ intervals (Figure 1 ). The altitude along the road ranges from $99 \mathrm{~m}$ (at $0.0 \mathrm{~km}$ and the east gate) to $572 \mathrm{~m}$ (at $10.0 \mathrm{~km}$ and the highest point), and then drops to $308 \mathrm{~m}$ (at $12.6 \mathrm{~km}$ and the west gate). One of our points overlooking Bala was at the -0.5 km mark, just before the east gate. Rainfall at Bala occurs in all months, least during February-July, mostly as afternoon thunderstorms during the August-October southwest monsoon, and mainly during the November-January south-east monsoon. During 2004, the annual rainfall was only $77 \%$ of the mean $(n=13)$, only at or above the monthly mean in 


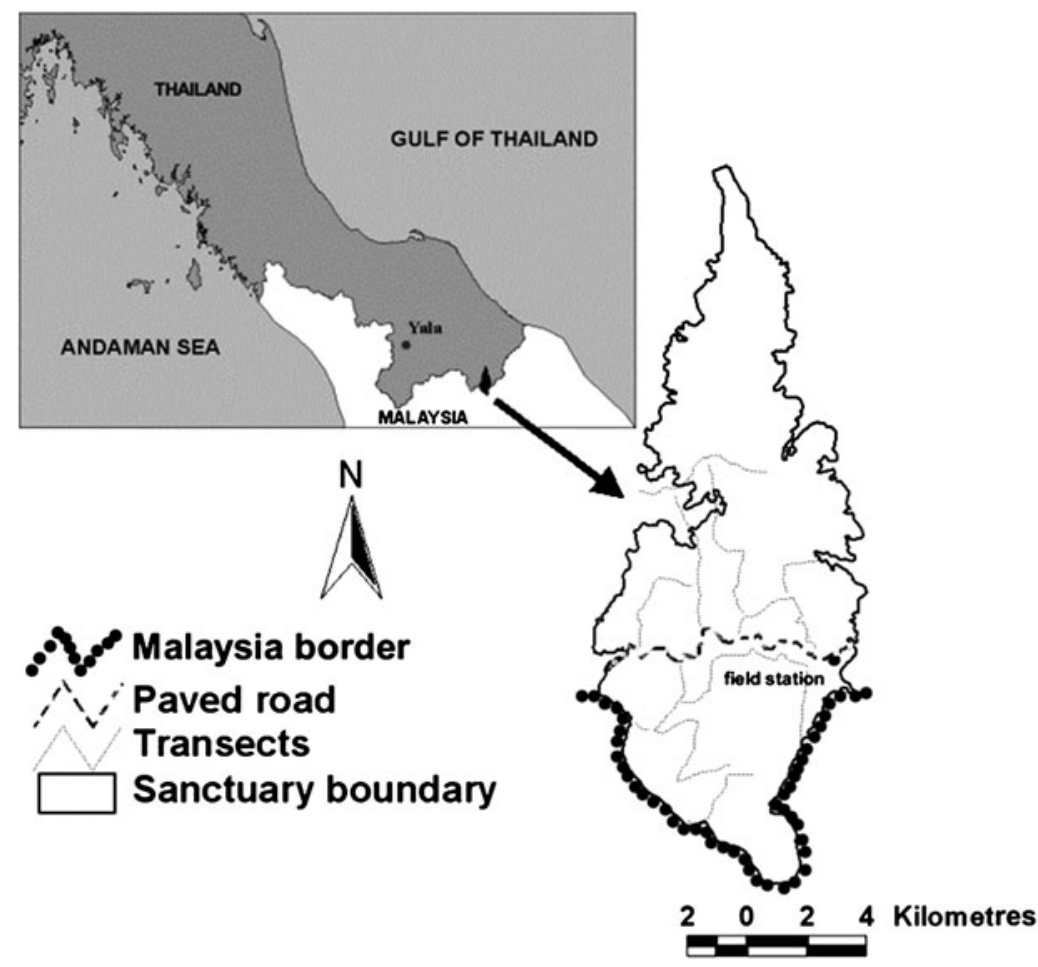

Figure 1. Map showing the position of Bala forest within southern Thailand and along the Malaysian border, the paved road passing through Bala, the previous line-transect trails on each side and the location of the Hala-Bala Resarch Station.

September-October and coincided with a 'mast-year' for tree fruiting. The mean annual temperature is $27^{\circ} \mathrm{C}$, with the hottest months March-May and coolest November-January, and the mean relative humidity is $82 \%$ (see Gale and Thongaree 2006, Kemp et al. 2007, 2009 for further details about Bala).

\section{Methods}

We estimated detection, dispersion and density of target species mainly by what we called 'lookout watches'. These were 1 -h observation periods made over large areas of forest canopy from one of 14 elevated lookout points (Figure 2; Table $S_{1}$ in online Supplementary Materials).

We chose our sites to compare our estimates for hornbills and Great Argus with earlier ones obtained within the same forest from along the road and trails on either side, and we collected new data for diurnal raptors. The previous in-forest studies were conventional distance sampling techniques conducted on hornbills, Great Argus and other rare birds during January 2001 to April 2002 (Figure 1; Gale and Thong-aree 2006). Eleven 3.0-11.4 km-long variable-width transects, a total of $68 \mathrm{~km}$, were surveyed monthly and Great Argus was also spot-mapped around the Hala-Bala Wildlife Research Station near the eastern end of the road (Figures 1 and 2; Thong-aree unpubl. data).

i) Lookout watches. We evaluated 20 of the most elevated lookout points along the road and selected 14 that offered the widest and most open views from which to see and/or hear large birds (Figure 2; Table S1; satellite image in Kemp et al. 2007). We recorded the 


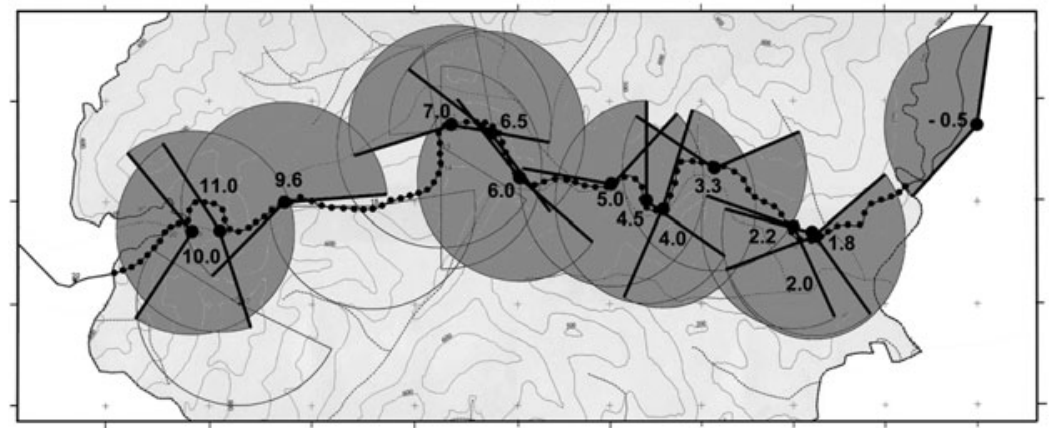

Figure 2. Section of topographical map showing the $12.6 \mathrm{~km}$ of paved road $(\bullet \bullet)$ through Bala sanctuary (shaded pale grey), with the 100-m contour lines (300) and the main stream beds (----) marked. The location of the 14 lookout points, selected from 20 possibilities, are also marked $(\bullet)$, each with their kilometrage along the road (including one $0.5 \mathrm{~km}$ east of Bala), fieldof-view (heavy black lines) and 1-km arc within the field of view (shaded dark grey).

location and altitude at each lookout point with a portable GPS (Garmin Etrex Vista), and the field of view available and direction of landmarks within that field as bearings accurate to the nearest $5^{\circ}$ using a handheld magnetic compass (Figure 2, Table $\mathrm{S}_{1}$ ). We also constructed a panoramic reference view from each lookout by stitching together a series of overlapping digital images (Arcsoft Panorama Maker 3.0), on which we marked the compass bearings recorded.

On a given day, one person watched from a lookout point for a period of $\mathrm{I}-\mathrm{h}$, sometimes for 2-6 hours successively, and sometimes from more than one point in the same day. Within each $\mathrm{I}$-h watch, we recorded each initial detection of a target species, whether we first saw or heard it, and its estimated location within our field-of-view. Using 1ox binoculars and a $28 \mathrm{x}$ spotting scope, we attempted to identify how many individuals were involved, their sex and age, and their subsequent movements and locations until we lost contact. We did not attempt to estimate the distance of each individual from the observer, since we found this difficult for sightings due to lack of reference points for individuals heard or in flight and/or deceptive given the rugged topography, and for calls due to interference from topography, vegetation, and/or noises of water and other animals. Instead, we estimated the approximate position and movements of the individual(s) relative to their direction, the topography and other landmarks, so that later we could plot these on 1:50,000 topographical maps. Any further detections made within the same $\mathrm{I}$-h lookout period assumed that birds seen and/or heard in the same general area as previously, or seen returning to the lookout area from the same general direction in which they departed, were the same individuals. We did not make lookout watches during high wind, heavy rain, when the noise of dripping or running water was intrusive, or if light rain lasted for longer than to min.

After making the first detection of an individual within each $\mathrm{I}$-h watch, we also recorded the interval to the nearest minute between subsequent sightings and vocalisations, but only if these were made at least $5 \mathrm{~min}$ after the previous detection. We chose this 5 -min interval since it was usually enough time for one bout of calling or movement to cease before initiation of a subsequent bout. Helmeted Hornbill was the only exception since the end of each bout of calling ends with a brief cackling 'laugh' (Haimhoff 1987) that allowed us to record intervals between each 'laugh' to the nearest minute.

ii) In-forest detections. In addition to lookout watches, we also recorded the same data for all target species seen or heard during in-forest excursions lasting one or more hours from where we lived at the Hala-Bala Research Station. We did this regardless of the activity, walking along the road or up to $2 \mathrm{~km}$ into the forest on adjacent trails, watching from other 
vantage points above or hides within the forest, or driving along the road. This provided us with an additional measure of unit effort, complemented and extended our more rigorous data from the $1-h$ lookout watches, and added to our data on detection by time of day and season, location, movement, call repetition, and territorial and nesting behaviour.

iii) Density estimation. We estimated the density of target species in three ways, two using data from lookout watches and one combining data from lookout watches and in-forest excursions. We estimated and sometimes measured each target species as visible and/or audible to at least $1 \mathrm{~km}$. Based on this, we calculated the area of possible detection from each lookout point as an arc of $1-\mathrm{km}$ radius between the measured angles of the field-of-view and/or hearing, plus an arc of $0.2 \mathrm{~km}$ radius on the steep slope behind the field of view but still within earshot. (Figure 2; Table SI). We did estimate a viewshed for each lookout point, to compensate for the topographical contours within each $1-\mathrm{km}$ arc, and the mean coverage of these TIN viewsheds comprising $84 \%$ of the I-km field-of-view arc (range 49-100\%; Table $\mathrm{S}_{1}$; TIN elevation surface using Arcview GIS 3.2 (Environmental Systems Research Institute, Inc.). However, since we estimated the average forest canopy to be c.30 $\mathrm{m}$ above the ground at most lookouts, and sometimes detected birds beyond the TIN surfaces, seen flying above or heard within the forest, we chose not to apply these viewshed areas in our estimates of density.

Our first estimate of density for each target species was the average for all $1_{4}$ lookouts of the mean number of individuals detected from each lookout per $\mathrm{km}^{2}$ surveyed per $\mathrm{I}$-h observation period $(n=34-58 \mathrm{~h}$ per lookout; Table S2).

Our second estimate of density for each species was the average for all ${ }_{14}$ lookouts of the highest number of breeding units detected during a single 1 -h watch from each lookout, converting this average to individuals per $\mathrm{km}^{2}$ (Table $\mathrm{S}_{3}$; Kemp et al. 2007).

Our third estimate of density for each species was derived from the location plots on 1:50,000 topographical maps of all visual and aural detections made from lookout watches plus in-forest excursions. These plots included all detections of individuals or breeding units, their movements, any known or suspected nest sites, and any sites of territorial conflict and/or boundary behaviour. We enhanced the accuracy of our plots by knowing our position relative to roads, contour lines, ridge tops, watercourses, trails, lookout sites, fields of view and sanctuary boundaries already marked on the maps. We interpreted these plots as a spot map that offered an alternative estimate of the numbers of core areas and hence species-units detected along the $13.1 \mathrm{~km}$ of road, and within the $500 \mathrm{~m}$ of either side or end of the road that approximated the maximum distance for in-forest detections.

\section{Results}

\section{Detection}

We detected all but one of the expected target species during our observations (nine hornbill, one pheasant, nine diurnal raptor species), with only Oriental Pied Hornbill unrecorded. We spent $620 \mathrm{~h}$ detecting species from lookout watches and $619 \mathrm{~h}$ from in-forest excursions, which we combined as monthly and hourly totals to compare the number of detections per unit time for each species from lookouts, during in-forest excursions and/or overall (Figure 3; Tables $\mathrm{S}_{2}$ and $\mathrm{S}_{4}$ ).

The time spent at each lookout during 2004 varied between months, but totals included at least $46 \mathrm{~h}$ of observation for most months (mean $50.3 \mathrm{~h}$, SD $5.4 \mathrm{~h}$, range $12-77 \mathrm{~h}$ ) and lookouts (mean $40.2 \mathrm{~h}, \mathrm{SD} 6.4 \mathrm{~h}$, range $34-58 \mathrm{~h}$ ), with least coverage during the first two months while we established the study (Figure 3; Table S2). Observations made during in-forest excursions, while of similar duration to those from lookouts, showed different emphases on the months and hours that were included (Figure 3; Table $\mathrm{S}_{4}$ ). We assumed that the combined totals for each month and daylight hour covered sufficient times, locations, habitats and altitudes to provide valid samples for diurnal and monthly comparisons both within and between target species.

Detection probability is important in population estimation, and we estimated significant variation in detection rates for each of the commoner target species by months of the year (Table $\mathrm{S}_{5}$ ) and 

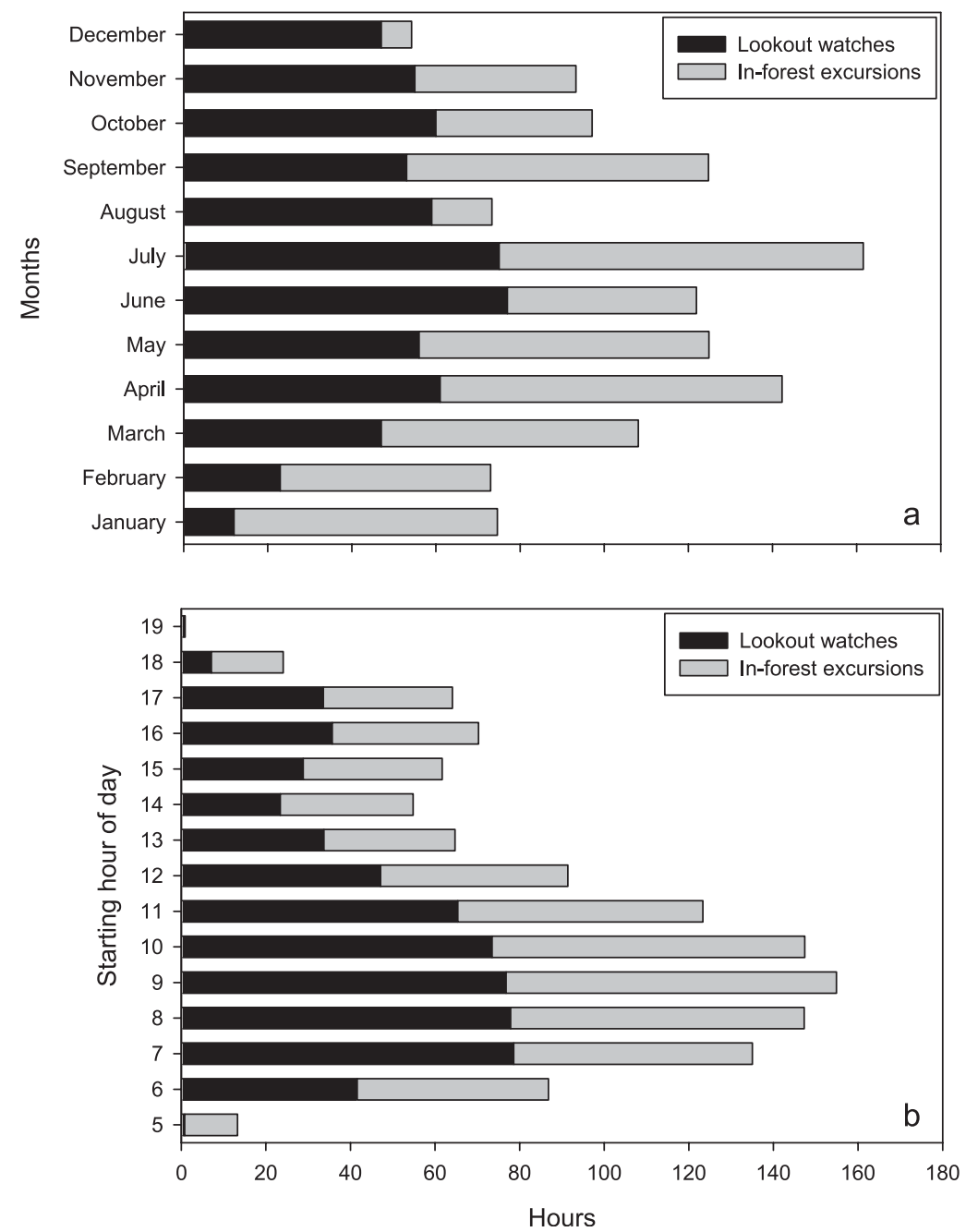

Figure 3. Histograms showing the proportion of observation hours conducted from supra-canopy lookout watches and in-forest excursions at Bala during 2004, a) per month and b) per hour of the day.

hours of the day (Table S6). For species with large samples of detections per month, we could calculate the ratio of initial detections made by seeing or hearing the species and significant indices of seasonal changes in visibility versus audibility (Table $\mathrm{S}_{5}$ ). Where a species was sufficiently vocal to generate an adequate sample per month or hour of the day, the number of times the loud calls were repeated provided significant indices of vociferousness, similar to, but different from, patterns for initial detection rates by sound and/or sight (Tables $\mathrm{S}_{5}$ and S6). While these results do extend our previous analyses of detection for hornbills (Kemp et al. 2007), we present here only examples of monthly variation among selected commoner species, due to the diversity of target species and their sampling coverage, with further details of monthly and diurnal detection for all species available online as Supplementary Materials (Figures $\mathrm{S}_{1}$ and $\mathrm{S}_{2} ;$ Tables $\mathrm{S}_{5}$ and S6).

We detected Rhinoceros Hornbill most frequently from December to May (Figure 4a), most visibly in February-March and most vociferously in August (Figure 5; Table $\mathrm{S}_{5}$ ). However, Great 

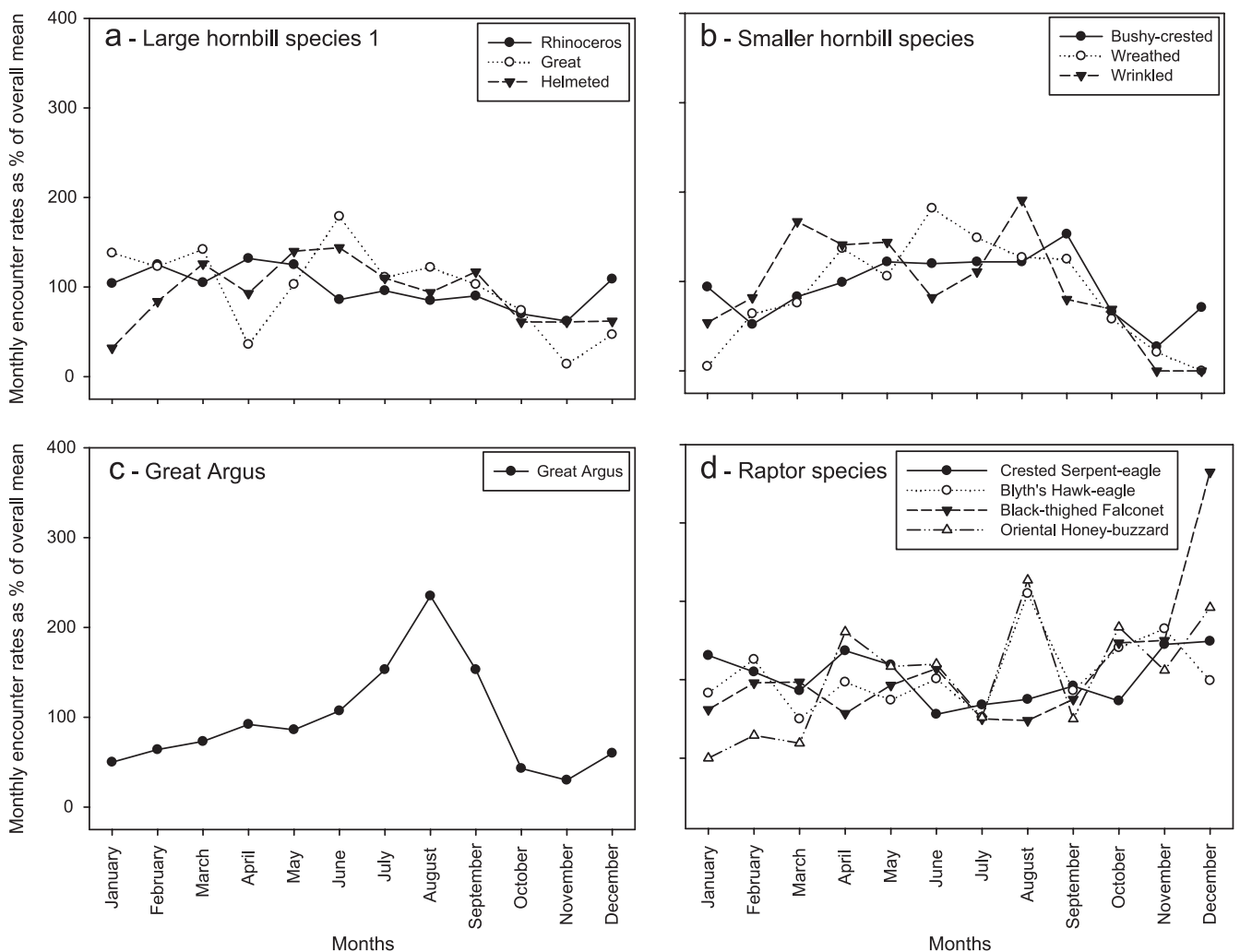

Figure 4. Line graphs linking the mean detection rates/month at Bala for the commoner target species, expressed as a percentage of the overall mean of all months of 2004, for a) three large hornbill species, b) three smaller hornbill species, c) Great Argus and d) four raptor species. 


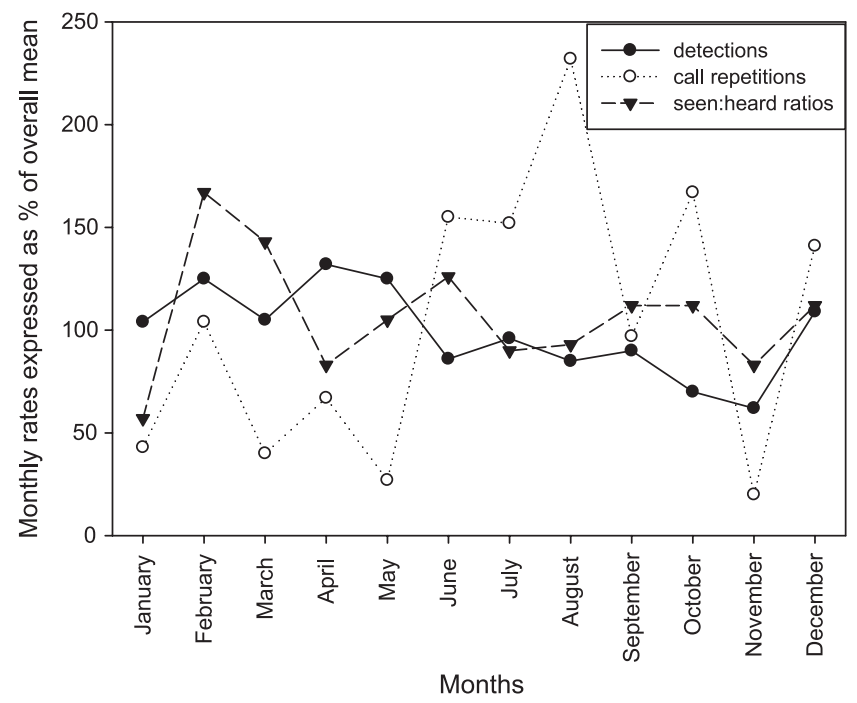

Figure 5. An example of seasonal variations in behaviours affecting detection showing line graphs for Rhinoceros Hornbill at Bala during 2004 that link the mean detection rate/month, seen:heard ratio/month and number of call repetitions/month, each expressed as a percentage of the overall mean.

Hornbill, similar in size and biology, was most often detected in June (Figure 4a) and most vociferous in August (Table $\mathrm{S}_{5}$ ), but with indistinct patterns, due perhaps to smaller sample sizes. The equally large but ecologically distinctive Helmeted Hornbill was inconspicuous for much of the year, with slightly more frequent detections in May-June (Figure 4a), more vociferous in March and more visible during February and June (Table $\mathrm{S}_{5}$ ).

The smaller Bushy-crested Hornbill differed in being most often detected from May to a peak in September (Figure $4 \mathrm{~b}$ ) and most vociferous in June-October (Table $\mathrm{S}_{5}$ ), but the ecologically similar White-crowned Hornbill was detected too infrequently $\left(n={ }_{15}\right)$ for analysis (Table $\left.S_{5}\right)$. Wreathed and Wrinkled Hornbills, both obvious when making regular flights above the forest canopy, their wing-beats audible even when not vocal, disappeared during the wettest monsoon season of November-January (Figure 4 b). When present, we detected Wrinkled Hornbill most frequently during March-August and Wreathed Hornbill a month later during April-September. We only detected Plain-pouched and Black Hornbills once each at the $4.5 \mathrm{~km}$ and $1.8 \mathrm{~km}$ lookouts respectively, and never detected Oriental Pied Hornbill.

We detected Great Argus only by the calls of males, which were above average during JulySeptember, with a marked peak in August (Figure 4c), and this pattern was even more obvious for its vociferousness $\left(\right.$ Table $\mathrm{S}_{5}$ ).

We detected Crested Serpent-eagle most frequently from November to January and in April (Figure 4d); it was most visible from August to October, and most vociferous in September and especially November-December (Table S5). Blyth's Hawk-eagle, also an aerial and vocal species, was detected most frequently in August and October-November (Figure 4d), and was most visible in November (Table $\mathrm{S}_{5}$ ). Black-thighed Falconet, only easily visible when perching in the open, was detected most frequently from October to a peak in December (Figure 4d). We detected Oriental Honey-buzzard least in January-March and most in April, August, October and December (Figure $4 \mathrm{~d}$ ), but the relatively small sample size of known residents, and the addition of difficult-to-separate migrants during April-August, made it difficult to interpret monthly variation. Other resident diurnal raptor species, detected too infrequently for analysis, were 
Bat Hawk ( $n=24$ detections, all but two near a nest below $1.8 \mathrm{~km})$, Lesser Fish-eagle $(n=4$, near streams at $3.3,4.5,5.0$ and $7.0 \mathrm{~km})$, Black Eagle $(n=2$, at $6.0 \mathrm{~km})$, Rufous-bellied Eagle $(n=13$, all but one near a nest at $4.5 \mathrm{~km})$ and Changeable Hawk-eagle $(n=1$, at $4.5 \mathrm{~km})$.

\section{Dispersion}

We had previously analysed the most frequent composition of units within which we detected each species of hornbill, namely singles (lone adults or calling males), adult pairs (with or without offspring) or cooperative groups (Kemp et al. 2007). Our results for hornbills, plus those of other target species, were adult pairs for Rhinoceros $(79 \%, n=685$ detections) and Great Hornbills $(67 \%$, $n=102)$; adult singles of either sex for Wreathed $(49 \%, n=221)$ and Wrinkled Hornbills $(74 \%$, $n=42)$; unsexed adult singles for Crested Serpent-eagle $(82 \%, n=293)$ and Blyth's Hawk-eagle $(86 \%, n=161)$, Oriental Honey-buzzard $(93 \%, n=59)$, and Black-thighed Falconet $(71 \%, n=$ 106); calling male singles for Helmeted Hornbill $(83 \%, n=552)$ and Great Argus (100\%, $n=253)$; and members of cooperatively breeding groups for Bushy-crested $(100 \%, n=157$, mean group size 4.9) and White-crowned Hornbills (100\%, $n=15$, mean group size 5.0).

When estimating breeding density from these species units, we scored each pair, singleton or group as two individuals, pairs forming the basic breeding and/or territorial unit, singles assumed to be half of monogamous pairs, and cooperative groups normally containing only a single alpha breeding pair. We tallied the highest number of these species units differentiated during a single I-h watch within the field of view arc of each lookout (Table $S_{3}$; Kemp et al. 2007) and used this total to represent the maximum number of potential breeding units and/or individuals detected per unit area. We also used these units as indicative of a breeding pair within each of the core areas spot-mapped along the road.

\section{Density}

From the lookout points, we observed a total area of $24.39 \mathrm{~km}^{2}$, equivalent to $21.9 \%$ of the area of Bala, but, since there was overlap between several of the lookout fields of view, the actual area of habitat observed was somewhat less (Figure 2; Table SI). For the spot maps, we counted the number of core areas of target species found within $500 \mathrm{~m}$ of the sides and the ends of the $13.1-\mathrm{km}$ road, a total area of $14.1 \mathrm{~km}^{2}$ or $12.6 \%$ of the area of Bala.

We based our three estimates of density for each target species on: 1 ) the overall mean number of individuals detected from each lookout area per 1-h lookout-watch (Tables 1a-i and S7); 2 ) the mean number of potential breeding individuals within the maximum number of species units detected during a single 1 -h lookout-watch (Tables $1 a-i i$ and $S_{3}$ ), and 3 ) the number of potential breeding individuals in the maximum and minimum number of core units within $500 \mathrm{~m}$ of the road (Table 1 b-i and -ii).

We then compared our three estimates of density with each other, with results from other techniques and studies at Bala (Table Ic-i), and with other estimates from comparable habitats and/or species elsewhere in the Indomalayan Region (Table Ic-ii).

Most of our estimates of density (Table $1 a$ and b), and all those at Bala from Gale and Thongaree (2006; Table 1c-i), fell within the range of densities recorded for the same or similar species of hornbill and Great Argus at other locations within South-East Asia (Table 1c-ii). Comparative data for diurnal raptors were sparse and inconclusive, so we only consider hornbills and Great Argus further.

The sequences of relative density estimated at Bala for the seven most abundant hornbill species differed with each method (Table 2). All four techniques indicated either Rhinoceros or Helmeted Hornbill as the most abundant, then Wreathed, Great or Bushy-crested Hornbill as next most abundant, and Wrinkled or White-crowned as least abundant. Compared to these hornbill species, we estimated Great Argus as $4^{\text {th }}$ most abundant from lookout watches, most abundant from spot maps, $5^{\text {th }}$ most abundant from line transects and $7^{\text {th }}$ most abundant for a previous spot map 
Table 1 . Estimated densities for all target species along $13.1 \mathrm{~km}$ of road through Bala forest using: a) coverage from 14 roadside lookouts over a total area of $24.36 \mathrm{~km}{ }^{2}$ for a-i) the overall mean number of individuals counted/1-h lookout watch and a-ii) the overall mean of the maximum number of breeding units (pairs, singletons or groups) in a single 1 -h watch, and b) spot maps with plots of sightings and behaviour within $500 \mathrm{~m}$ of the road and covering a total area $14.1 \mathrm{~km}{ }^{2}$ to count core areas $(=\mathrm{breeding}$ units) for $b-i)$ minimum number of core areas and b-ii) maximum number of core areas. Comparative densities from line transects $\left({ }^{*}\right)$ or nesting densities (+) are presented: $\left.c-i\right)$ for Bala hornbills (Gale and Thong-aree 2006) and Great Argus (Gale and Thongaree unpubl. data) and c-ii) for elsewhere in South-East Asia (hornbill compilations in Gale and

Thongaree 2006, Kinnaird and O'Brien 2007), all other species (Wells 1999), diurnal raptors (Ferguson-Less and Christie 1999) and Collared Falconet (Sivakumar et al 2004)).

\begin{tabular}{|c|c|c|c|c|c|c|c|c|c|c|c|c|c|c|c|c|c|}
\hline \multirow{2}{*}{$\begin{array}{l}\text { Density estimates } \\
\text { based on different } \\
\text { sampling techniques }\end{array}$} & \multicolumn{17}{|c|}{ Densities of target species** (individuals $\mathrm{km}^{-2}$ ) } \\
\hline & $\mathrm{RH}$ & GH & $\mathrm{HH}$ & WH & WRH & $\mathrm{BCH}$ & $\mathrm{WCH}$ & ARG & SE & $\mathrm{BE}$ & FAL & HBZ & CE & $\mathrm{BH}$ & RBE & LFE & BLE \\
\hline \multicolumn{18}{|l|}{ a) Lookout coverage $(n=14)$ : } \\
\hline $\begin{array}{l}\text { i) Mean number of individuals/ } \\
\text { watch }\end{array}$ & 1.23 & 0.22 & 0.62 & 0.34 & 0.05 & 0.14 & 0.02 & 0.23 & 0.26 & 0.19 & 0.15 & 0.07 & 0.04 & 0.05 & 0.00 & 0.01 & 0.00 \\
\hline SD & 0.52 & 0.26 & 0.27 & 0.17 & 0.05 & 0.11 & 0.04 & 0.25 & 0.15 & 0.09 & 0.16 & 0.06 & 0.10 & 0.11 & 0.01 & 0.03 & 0.01 \\
\hline $\begin{array}{l}\text { ii) Mean of maximum units in } \\
\text { single watch }\end{array}$ & 4.26 & 1.94 & 4.75 & 3.54 & 0.99 & 1.97 & 0.72 & 2.73 & 3.29 & 2.69 & 1.62 & 1.58 & 0.33 & 0.45 & 0.71 & 0.28 & 0.24 \\
\hline SD & 1.03 & 1.52 & 1.92 & 1.14 & 0.94 & 0.87 & 0.86 & 1.79 & 1.01 & 0.79 & 1.12 & 0.74 & 0.65 & 0.81 & 0.47 & 0.55 & 0.46 \\
\hline \multicolumn{18}{|l|}{$\begin{array}{l}\text { b) Spot-maps of core areas } \\
\text { along road from lookout } \\
\text { and in-forest sightings: }\end{array}$} \\
\hline i) Minimum species units (core $n=$ ) & $\begin{array}{l}3.68 \\
(27)\end{array}$ & $\begin{array}{c}0.43 \\
(3)\end{array}$ & $\begin{array}{l}6.52 \\
(47)\end{array}$ & $\begin{array}{l}0.28 \\
(2)\end{array}$ & $\begin{array}{l}0.14 \\
(1)\end{array}$ & $\begin{array}{c}1.84 \\
(13)\end{array}$ & $\begin{array}{c}0.99 \\
(7)\end{array}$ & $\begin{array}{r}7 \cdot 38 \\
(52)\end{array}$ & $\begin{array}{r}1.56 \\
(11)\end{array}$ & $\begin{array}{c}0.71 \\
(5)\end{array}$ & $\begin{array}{c}0.85 \\
(6)\end{array}$ & $\begin{array}{l}0.43 \\
(3)\end{array}$ & $\begin{array}{c}0.00 \\
(0)\end{array}$ & $\begin{array}{l}0.14 \\
(1)\end{array}$ & $\begin{array}{l}0.14 \\
(1)\end{array}$ & $\begin{array}{l}0.14 \\
(1)\end{array}$ & $\begin{array}{l}0.14 \\
(1)\end{array}$ \\
\hline ii) Maximum species units (core $n=$ ) & $\begin{array}{l}4.26 \\
(30)\end{array}$ & $\begin{array}{c}0.71 \\
(5)\end{array}$ & $\begin{array}{l}7.94 \\
(56)\end{array}$ & $\begin{array}{l}1.13 \\
(8)\end{array}$ & $\begin{array}{l}0.28 \\
(2)\end{array}$ & $\begin{array}{l}2.13 \\
(15)\end{array}$ & $\begin{array}{c}0.99 \\
(7)\end{array}$ & $\begin{array}{r}9 \cdot 36 \\
(66)\end{array}$ & $\begin{array}{c}2.27 \\
(16)\end{array}$ & $\begin{array}{c}0.85 \\
(6)\end{array}$ & $\begin{array}{l}0.99 \\
(7)\end{array}$ & $\begin{array}{l}0.71 \\
(5)\end{array}$ & $\begin{array}{l}0.14 \\
(1)\end{array}$ & $\begin{array}{l}0.14 \\
(1)\end{array}$ & $\begin{array}{c}0.28 \\
(2)\end{array}$ & $\begin{array}{l}0.14 \\
(1)\end{array}$ & $\begin{array}{l}0.14 \\
(1)\end{array}$ \\
\hline \multirow{2}{*}{\multicolumn{18}{|c|}{$\begin{array}{l}\text { c) In-forest line transects* or } \\
\text { nesting pairs }{ }^{+} \\
\text {i) Bla }\end{array}$}} \\
\hline $\begin{array}{l}\text { i) Bala } \\
\text { Mean density }\end{array}$ & & & & & & & & & & & & & & & & & \\
\hline & $\begin{array}{l}2.69^{*} \\
1.99\end{array}$ & $\begin{array}{l}0.12^{*} \\
0.08\end{array}$ & $\begin{array}{l}1.21^{*} \\
0.81\end{array}$ & $0.69^{*}$ & $0.08^{*}$ & $\begin{array}{l}0.64^{*} \\
0.32\end{array}$ & $\begin{array}{l}0.08^{*} \\
0.03\end{array}$ & $0.20^{*}$ & & & & & & & & & \\
\hline $\begin{array}{l}\text { Lower } 95 \% \text { CI } \\
\text { Upper } 95 \% \text { CI }\end{array}$ & $\begin{array}{l}1.99 \\
3.64\end{array}$ & $\begin{array}{l}0.08 \\
0.19\end{array}$ & $\begin{array}{l}0.81 \\
1.82\end{array}$ & $\begin{array}{l}0.40 \\
1.18\end{array}$ & $\begin{array}{l}0.04 \\
0.13\end{array}$ & $\begin{array}{l}0.32 \\
1.28\end{array}$ & $\begin{array}{l}0.03 \\
0.24\end{array}$ & 0.06 & & & & & & & & & \\
\hline $\begin{array}{l}\text { Upper } 95 \% \text { CI } \\
\text { CV }\end{array}$ & $\begin{array}{l}3.04 \\
0.14\end{array}$ & $\begin{array}{l}0.19 \\
0.21\end{array}$ & $\begin{array}{l}1.82 \\
0.19\end{array}$ & $\begin{array}{l}1.18 \\
0.26\end{array}$ & $\begin{array}{l}0.13 \\
0.26\end{array}$ & $\begin{array}{l}1.28 \\
0.36\end{array}$ & $\begin{array}{l}0.24 \\
0.40\end{array}$ & $\begin{array}{l}0.61 \\
0.58\end{array}$ & & & & & & & & & \\
\hline \multirow{2}{*}{\multicolumn{12}{|c|}{ ii) Elsewhere in South-East Asia }} & & & & & & \\
\hline $\begin{array}{l}\text { 11) Elsewhere in South-East Asia } \\
\text { Lowest }\end{array}$ & 0.5 & 0.7 & 0.3 & 0.1 & 0.1 & 1.3 & 0.3 & 0.15 & $0.3+$ & & $0.7^{*}$ & $0.4^{+}$ & & $0.004+$ & & $0.4^{+}$ & $0.03+$ \\
\hline Highest & 20.0 & 9.6 & 17.0 & 46.0 & 21.0 & 5.8 & 4.2 & 2.25 & 0.4 & & 1.3 & 0.8 & & & & 0.7 & \\
\hline
\end{tabular}

${ }^{* *}$ RH - Rhinoceros Hornbill, GH - Great Hornbill, HH - Helmeted Hornbill, WH - Wreathed Hornbill, WRH - Wrinkled Hornbill, BCH - Bushy-crested Hornbill, WCH White-crowned Hornbill, ARG - Great Argus, SE - Crested Serpent-eagle, BE - Blyth's Hawk-eagle, FAL - Black-thighed Falconet, HBZ - Oriental Honey-buzzard, CE Changeable Hawk-eagle, BH - Bat Hawk, RBE - Rufous-bellied Eagle, LFE - Lesser Fish-eagle, BLE - Black Eagle.

Changeable Hawk-eagle, BH - Bat Hawk, RBE - Rufous-bellied Eagle, LFE - Lesser Fish eagle, BLE - Black Eagle. 
Table 2. Density sequence indicating relative abundance of the seven commonest hornbill species at Bala, and Great Argus, using four different estimates (from Table 1).

\begin{tabular}{|c|c|c|c|c|c|c|c|c|}
\hline \multirow{2}{*}{$\begin{array}{l}\text { Density method } \\
\text { (individuals } \mathrm{km}^{-2} \text {, } \\
\text { Table } 1 \text { ) }\end{array}$} & \multicolumn{8}{|c|}{ Density sequence of hornbill and pheasant species } \\
\hline & 1 & 2 & 3 & 4 & 5 & 6 & 7 & 8 \\
\hline $\begin{array}{l}\text { a) } 1 \text {-hr lookout } \\
\text { watches: } \\
\text { i) Mean total }\end{array}$ & Rhinoceros & Helmeted & Wreathed & Great & $\begin{array}{l}\text { Great } \\
\text { Argus }\end{array}$ & $\begin{array}{l}\text { Bushy- } \\
\text { crested }\end{array}$ & Wrinkled & $\begin{array}{l}\text { White- } \\
\text { crowned }\end{array}$ \\
\hline $\begin{array}{l}\text { a) I-hr lookout } \\
\text { watches: } \\
\text { ii) Mean highest } \\
\text { units }\end{array}$ & Helmeted & Rhinoceros & Wreathed & $\begin{array}{l}\text { Bushy- } \\
\text { crested }\end{array}$ & $\begin{array}{l}\text { Great } \\
\text { Argus }\end{array}$ & Great & Wrinkled & $\begin{array}{l}\text { White- } \\
\text { crowned }\end{array}$ \\
\hline $\begin{array}{l}\text { b) Spot-mapping: } \\
\text { i) core and } \\
\text { ii) maximum } \\
\text { units }\end{array}$ & $\begin{array}{l}\text { Great } \\
\text { Argus }\end{array}$ & Helmeted & Rhinoceros & Great & Wreathed & $\begin{array}{l}\text { Bushy- } \\
\text { crested }\end{array}$ & $\begin{array}{l}\text { White- } \\
\text { crowned }\end{array}$ & Wrinkled \\
\hline $\begin{array}{l}\text { c) Line transects: } \\
\text { i) Gale and } \\
\text { Thong-aree } \\
\text { (2006) }\end{array}$ & Rhinoceros & Helmeted & Wreathed & $\begin{array}{l}\text { Bushy- } \\
\text { crested }\end{array}$ & Great & $\begin{array}{l}\text { Great } \\
\text { Argus }\end{array}$ & Wrinkled & $\begin{array}{l}\text { White- } \\
\text { crowned }\end{array}$ \\
\hline
\end{tabular}

compared to our spot map ( $1.39 \mathrm{~km}^{-2}$; Gale and Thongaree, unpubl. data). Notably, relative density of hornbill species estimated by lookout and line transect techniques were most similar when based on mean numbers of individuals per unit time and/or area, while lookout and spot map techniques based on maximum numbers of possible breeding units were least consistent even though statistically dependent through using much of the same data on species units (Table 2).

The differences in estimated density for each of our techniques, relative to the results from conventional line transects, were also not consistent, either for each technique or for species (Table 3). Our lookout estimates compared to line transect estimates, both based on mean number of individuals, were almost double for Great Hornbill (1.8 times), about half for most other hornbills (0.5-0.6 times), only a fifth for Bushy-crested and White-crowned Hornbills (0.2 times), but most similar for Great Argus (1.2 times). Our estimates based on maximum number of breeding units compared to line transect estimates were consistently higher and more variable for hornbill species (1.6-16.2 times), and for Great Argus (13.7 times). Our spot map estimates, based on minimum or maximum number of core units, showed the least variation within species, with maximum estimates usually only slightly higher. However, for comparisons between hornbill species with line transect estimates, minimum densities ranged over $0.4-12.4$ times and maximum numbers over 1.6-12.4 times, while for Great Argus the differences were even higher at 19.1-24.3 times. Some of our density estimates would have shown greater or lesser differences from line transect values if we included error values (standard deviation values for lookout estimates, minimum vs. maximum values for spot map estimates, and $95 \%$ confidence indices (CI) or coefficient of variation (CV) for line transect estimates), but considerable patterns of variability still remained between techniques and/or species.

\section{Discussion}

\section{Detection}

Measures of detection for each species showed significant seasonal and diurnal patterns that indicate changes in either detectable behaviour or abundance, or both. Where we expect species to 
Table 3. Comparison of our estimates of hornbill and pheasant densities at Bala during 2004 (Table 1a and $\mathrm{Ib}$ ) with those determined about three years earlier by the well-established technique of variable-width line transects (Table 1c, Gale and Thong-aree 2006).

\begin{tabular}{|c|c|c|c|c|c|c|c|c|}
\hline \multirow{2}{*}{$\begin{array}{l}\text { Our estimated densities as } \\
\text { proportions of earlier } \\
\text { line-transect densities }\end{array}$} & \multicolumn{8}{|c|}{ Hornbill and pheasant species } \\
\hline & Rhinoceros & Great & Helmeted & Wreathed & Wrinkled & $\begin{array}{l}\text { Bushy- } \\
\text { crested }\end{array}$ & $\begin{array}{l}\text { White- } \\
\text { crowned }\end{array}$ & $\begin{array}{l}\text { Great } \\
\text { Argus }\end{array}$ \\
\hline \multicolumn{9}{|l|}{ Per 1-hour lookout watch: } \\
\hline a-i) Mean no. individuals & 0.5 & 1.8 & 0.5 & 0.5 & 0.6 & 0.2 & 0.2 & 1.2 \\
\hline $\begin{array}{l}\text { a-ii) Maximum no. } \\
\text { breeding units }\end{array}$ & 1.6 & 16.2 & $3 \cdot 9$ & 5.1 & 12.4 & 3.1 & 9.0 & $13 \cdot 7$ \\
\hline \multicolumn{9}{|l|}{$\begin{array}{l}\text { Spot maps of core areas } \\
\text { within } 500 \mathrm{~m} \text { road: }\end{array}$} \\
\hline $\begin{array}{l}\text { b-i) Minimum no. core } \\
(=\text { breeding }) \text { units }\end{array}$ & 1.4 & 3.6 & $5 \cdot 4$ & 0.4 & 1.8 & 2.9 & 12.4 & 36.9 \\
\hline $\begin{array}{l}\text { b-ii) Maximum no. core } \\
\text { (= breeding) units }\end{array}$ & 1.6 & $5 \cdot 9$ & 6.6 & 1.6 & $3 \cdot 5$ & $3 \cdot 3$ & 12.4 & 46.8 \\
\hline
\end{tabular}

be resident, such as Rhinoceros, Helmeted, Bushy-crested and White-crowned Hornbills, these changes probably indicate variation in detection, but for species known to make seasonal and/or long-distance movements, such as Wreathed and Wrinkled Hornbills (Thong-aree 2007), changes probably also indicate population fluctuations. We also expect breeding status to have an influence on the seasonal detection of each species, as described in more detail in online Supplementary Information (Tables $\mathrm{S}_{5}$ and $\mathrm{S} 8$ ).

If our year-round measures of detection for each species do represent consistent seasonal and diurnal variation, it should be possible to apply these data in planning surveys during periods with a maximum probability of detection, and/or calibrating survey results collected at less detectable times of day or year. We predict that if such calibrations make previous and future survey data more consistent across days and seasons, then our results will represent reasonably accurate measures of detection. However, if they decrease consistency, either they are inadequate measures of detection, or other factors, such as movements into or out of the area and/or breeding status affecting abundance, are the main seasonal influences on population detection, numbers and/or density.

\section{Dispersion}

We expect all hornbill and raptor target species to be monogamous when breeding: due in hornbills to the female sealing herself into the nest cavity before egg-laying and being fed by the male (Kemp 1995, 2001, Kinnaird and O'Brien 2007), and in raptors to the male provisioning the female at the nest (Ferguson-Lees and Christie 1999). This suggests that our estimation of species units as indicative of breeding pairs is valid, but assumes that the sex ratio of breeding adults is even when singles comprise the breeding unit used to estimate density. Great Argus is an exception, since we only detected displaying males, mainly during the courtship season, when we expect an unknown number of females to visit calling males for breeding (Wells 1999), and our high estimated density of Helmeted Hornbills may also suggest that not all calling males pair with females.

However, we know few details of the spatial and temporal dispersion of target species. We expect most to be territorial, at least around the active nest (or display court for male Great Argus), but the size of the territory/home range and extent and regularity of seasonal movements further away are uncertain, especially for hornbills (Wells 1999, Kinnaird and O'Brien 2007). In our study, only Wreathed and Wrinkled Hornbill definitely left the study area during the non-breeding season, while passage migrants augmented boreal summer numbers of Oriental Honey-buzzard. 
All other species appeared to be resident, with regular spacing of sightings, core areas, and nesting or territorial behaviour that suggested sedentary and restricted home ranges in Rhinoceros, Great, Helmeted, Bushy-crested and White-crowned Hornbills, Great Argus and the more abundant species of diurnal raptors.

\section{Density}

The actual densities of target species surveyed are usually unknown, as at Bala, so while one cannot verify or calibrate estimates of density, any inconsistencies between survey periods and/or techniques indicate either temporal change in abundance or differences in bias and/or error. We only had sufficient data for the seven most abundant hornbill species and Great Argus at Bala to compare our estimates of density against a baseline of line transect estimates from three years earlier (Gale and Thong-aree 2006; Table 1). This approach assumes that line transect values, with their well-tested methodology, were the most reliable comparison for our results and also that hornbill numbers at Bala have not changed significantly since the line transect estimates, and that the areas surveyed were not significantly different in habitat quality or extent $\left(\leq 54 \mathrm{~km}^{2}\right.$ by line transect, based on maximum truncating distances of $400 \mathrm{~m}$ for $68 \mathrm{~km}$ of trails vs. $24.39 \mathrm{~km}^{2}$ from lookouts and $13.6 \mathrm{~km}^{2}$ for roadside spot maps).

We found little consistency between techniques and species, only that in relative abundance Rhinoceros or Helmeted Hornbills were most abundant, Wrinkled or White-crested Hornbills least, and Great, Wreathed and Bushy-crested Hornbills intermediate but in no consistent order, while Great Argus varied from $1^{\text {st }}$ to $7^{\text {th }}$ position among these hornbills (Tables 1 and 2 )

Our initial estimate of density from lookouts, using mean numbers of total individuals, was the closest equivalent to what line transects recorded (Table 1 a-i vs. c-i). Both estimates agreed on the relative abundance of species, except for Great Hornbill being elevated from $5^{\text {th }}$ to $4^{\text {th }}$ position in our estimate (Table 2). Our results estimated about half the densities for four canopy-living species (0.5-0.6 times), were slightly higher for terrestrial Great Argus (1.2 times) and much higher for canopy-living Great Hornbill (1.8 times), but much lower for the predominantly subcanopy-living Bushy-crested and White-crowned Hornbills (0.2 times; Table 3). Our lower values for canopy-living species coincide with the total area of the arcs sampled from our lookouts being about half that covered by line transects, but may also result from more pristine habitats further away from the road on transect lines (Figure 1). Our promotion in relative abundance, and considerably higher density estimate for Great Hornbill, similar in behavioural ecology to Rhinoceros Hornbill, suggests it may have been more abundant during our surveys, while our technique from lookout watches over forest apparently underestimated the two sub-canopy species.

The use of number of species units to represent breeding pairs in our other two estimates, rather than total number of individuals, should make our estimates conservative since we excluded unpaired and immature individuals, even though in some species we observed a few larger flocks of sub-adults, or non-breeding helpers in cooperative breeding groups (Table $\mathrm{S}_{3}$ ). Our estimates from lookouts using maximum species units from a single 1 -h watch were consistently higher than those from line transects for all species, by 1.6-16.2 times, with Great Hornbill showing the greatest difference and supporting our contention that this species was more abundant during our survey (Table 3). For the most abundant and sedentary Rhinoceros and Helmeted Hornbills, our lookout results were within the confidence intervals of the line transects (Table 1). For such difficult-to-detect species as Bushy-crested and White-crowned Hornbills, our use of the highest I-h count of species units derived from long sampling periods at lookout watches $(38-54$ hours, Table $\mathrm{S}_{3}$ ) may have ensured they were now better represented than in line transects (3.19.0 times). For such wide-ranging aerial species as Wreathed and Wrinkled Hornbill, we may have overestimated their abundance by scoring them as a potential species unit even if they just passed by a lookout, even though it may not have been their core area; however, their numbers may have been higher due to the fruits available in this mast year. 
Estimates from our spot maps, also using species units but over the smaller area within $500 \mathrm{~m}$ of the road, were less variable but ranged above and below line transect estimates for minimum number of core units (0.4-12.4 times) but were always higher for maximum number of core units (1.6-12.4 times; Table 3). Great Hornbill, again among the higher over-estimates (3.6-5.9 times), supported our contention of its greater abundance in 2004. White-crowned Hornbill, subjectively the least detectable species, living in the sub-canopy and with the softest call, was also most overestimated compared to line transects (12.4 times), probably because spot-mapping included sightings made during in-forest excursions of groups not detected from lookouts, which applied less to the sub-canopy but noisy Bushy-crested Hornbill (2.9-3.3 times). This species and the two canopy-living Rhinoceros and Wreathed Hornbills (1.4-1.6 and $0.4-1.6$ respectively) were most similar to line-transect estimates, but Helmeted Hornbill (5.4-6.6 times) and especially Great Argus (36.9-46.8 times) were considerably higher. We detected the latter two species as calling males, and high counts for this wary hornbill, or covering the peak display period of the pheasant, probably improved our detection of maximum numbers, even if sex ratios were even.

Our estimates of density for Great Argus by its roadside spot map (7.38-9.36 males km²) were much higher than an earlier spot map in the same forest $\left(1.39 \mathrm{~km}^{-2}\right.$; Gale and Thong-aree, unpubl. data), but less so than our unpublished estimate obtained during a study of nocturnal birds (3.68 males $\mathrm{km}^{-2} ;$ Kemp et al. 2009). At night, males seemed more approachable and audible in their replies to tape noises, and so nocturnal playback using the pheasant's own calls might offer an additional technique to estimate its numbers and density, especially if conducted during the peak calling period in August.

For diurnal raptors, we could only find a line-transect estimate for the congeneric Collared Falconet Microhierax caerulescens in India that was within the range of our results for Blackthighed Falconet (Sivakumar et al. 2004; Table 1).

\section{Factors affecting our results}

The exact area covered visually or aurally within a lookout arc depends on the visibility and audibility of each species, and the effect this has on their detection distances within the biotic and abiotic environment. We showed that the detection of each species varied seasonally and diurnally, but conditions for recording each species also vary at each lookout and during each $1-h$ watch. Mist and cloud cover, vegetation density, and air clarity all affect visual detection, while air density, wind direction and strength, water noises and sounds from other animals (e.g. cicadas, gibbons, orthopterans) affect aural detection. Since none of these factors was constant, most varied independently, and none were controlled for, we had to assume that their effects were cancelled out over an adequate spatial and temporal sample.

Despite providing some comparatively high estimates of density, we based our counts on conservative numbers for three reasons. First, we recorded only minimum numbers from each lookout, used only the most obvious population units detected within the lookout and road areas, ignored non-breeding and immature vagrants and group members, and assumed only one breeding pair per cooperative group. Even using the highest number of breeding units detected within a 1-h lookout watch was conservative, because one might record more units with greater sampling effort. Second, we used a standard $1-\mathrm{km}$ radius within which we expected to detect target species from each lookout point, although we probably detected species less accurately the further away (possibly compensated for by recording others more than $1 \mathrm{~km}$ away). Third, we assumed that the habitat on both sides of the road was uniformly suitable for all species, even though we know that some species have altitudinal preferences (Kemp et al. 2007), indicated by variations in density between lookout sites that may also reflect other aspects of habitat suitability and/or preference (Table S7). The assumption of uniform habitat is obviously not true, especially for the road verge where engineering works and forest clearance have altered the forest habitat. This makes our estimates even more conservative, probably only slightly so for lookout watches, given 
Table 4. The proportion that our lowest and highest estimates of density for target species at Bala during 2004 form of the highest recorded density for each target species elsewhere in Southeast Asia (based on data in Table 1 , margins of error excluded, nd = no data available).

\begin{tabular}{llllllllllll}
\hline $\begin{array}{l}\text { Our estimates } \\
\text { of density as } \\
\text { proportion }\end{array}$ & Target species at Bala* \\
\cline { 2 - 7 } \\
of highest \\
$\begin{array}{l}\text { South-East } \\
\text { Asian estimate: }\end{array}$
\end{tabular}

*Target species: RH - Rhinoceros Hornbill, GH - Great Hornbill, HH - Helmeted Hornbill, WH - Wreathed Hornbill, WRH - Wrinkled Hornbill, BCH - Bushy-crested Hornbill, WCH - White-crowned Hornbill, ARG Great Argus, SE - Crested Serpent-eagle, BE - Blyth's Hawk-eagle, FAL - Black-thighed Falconet, HBZ - Oriental Honey-buzzard, CE - Changeable Hawk-eagle, BH - Bat Hawk, RBE - Rufous-bellied Eagle, LFE - Lesser Fisheagle, BLE - Black Eagle.

the large scale over which we recorded detections relative to the width of the verge, but maybe significant for the 500-m width of spot-map estimates.

Estimation of density from lookouts was probably most sensitive to how we determined the area within which we considered a species detectable. We consider our range of density estimates as modal figures, likely to overestimate density for noisy and/or visible species detectable at the greatest distances, or to underestimate density for quiet or secretive species, especially in such steep, broken and vegetated topography as at Bala. Techniques that may improve the accuracy of estimation include use of a rangefinder to measure visibility and audibility of each species at different distances, GIS viewshed analysis based on forest canopy areas actually visible from a lookout point rather than ground topography, and trials with call playback to calibrate audibility distances for each species.

Comparison of our estimates with the highest recorded elsewhere in South-East Asia offers an index of habitat suitability at Bala (Table 4), suggesting good habitat for Great Argus, Crested Serpent-eagle, Bat Hawk, Lesser Fish-eagle and Black Eagle (2.0-35.0 times denser than anywhere else) and average habitat for other raptors, where known (0.8-0.9 times). However, habitats at Bala appear to be suboptimal for hornbills (< 0.1-0.5 times), best for Helmeted and Bushy-crested Hornbills but worst for Wreathed and Wrinkled Hornbills. All hornbill species in Thailand are considered threatened, especially the Sundaic species that only just extend into the southern peninsula (Round 1985, Poonswad 1993) and for which Bala is one of the few national conservation areas.

\section{Conclusions}

Lookout watches, which extend in space and time well beyond the relatively brief and local coverage offered by line transects or point counts, may offer more effective results for those species at seasons and times of day with low detection for target species (cf. Diefenbach et al. 2007). Our study suggests that we underestimate densities of large mobile birds that occur at low densities when using standard distance sampling techniques, especially if seasonal and diurnal variation in detection of each species is not considered, nor the influence of their behavioural ecology.

Our results also suggest that where suitable lookout points are available or creatable, their use might be more efficient in time and person-effort than line or point transects (Kemp et al. 2007), enabling more regular surveys of population trends. Especially if combined with spot maps, conducted repeatedly from lookouts that survey an extensive area of habitat, and using the best 
combination of observers, seasons, times of day and mapping technology. Subsets of data from our observation periods and locations might be explored further to establish the most efficient survey duration, extent, and timing, and to calibrate bias in detection and availability, especially for the many vocal target species with prompt detection times that were included in our study (Alldredge et al. 2007, Kemp et al. 2007).

\section{Supplementary Material}

The online supplementary materials for this article can be found at journals.cambridge.org/bci.

\section{Acknowledgements}

BIOTEC funded our year in Thailand and the support of their Director Dr Morakot Tanticharoen and her staff, in particular Kuhns Therrapatt Prasansakij, Kutilda Lamduan and Chimaiporn Watemaha, was appreciated. The Wildlife Conservation Office of the Department of National Parks, Wildlife and Plant Conservation allowed us to work in the Hala-Bala Wildlife Sanctuary. At Bala we received all manner of assistance and support from the Chief of Hala-Bala Wildlife Research Station, Kuhn Siriporn Thong-aree, and her staff, and from Kuhn Sunthorn Toadum of The Wild Flowering and Ornamental Plant Collection Project in The South of Thailand, and his staff. The Hornbill Project Thailand, led by Prof Pilai Poonswad, continued with its muchappreciated logistical and moral support of our work in Thailand from their offices in Bangkok, while Warren Boggs, then at Chulalongkorn University, performed our GIS analyses.

\section{References}

Alldredge, M. W., Pollock, K. H., Simons, T. R., Collazo, J. A. and Shriner, S. A. (2007) Timeof-detection method for estimating abundance from point-count surveys. Auk 124: 653-664.

Diefenbach, D. R., Marshall, M. R., Mattice, J. A. and Brauning, D. W. (2007) Incorporating availability for detection in estimates of bird abundance. Auk 124: 96-106.

Ferguson-Lees, J. and Christie, D. A. (1999) Raptors of the world. London: Christopher Helm.

Gale, G. and Thong-aree, S. (2006) Density estimates of nine hornbill species in a lowland forest site in southern Thailand. Bird Conserv. Int. 16: 57-69.

Haimhoff, E. H. (1987) A spectrographic analysis of the loud calls of Helmeted Hornbills Rhinoplax vigil. Ibis 129: 319-326.

Kemp, A. C. (1995) The hornbills, Bucerotiformes. Oxford, UK: Oxford University Press.

Kemp, A. C. 2001. Family Bucerotidae (hornbills). Pp. 436-508 in J. del Hoyo, A. Elliott and J. Sargatal, eds. Handbook of the birds of the world. Volume 6. Mousebirds to hornbills. Barcelona, Spain: Lynx Edicions.
Kemp, A. C., Kemp, M. I. and Thong-aree, S. (2007) How long must one watch over a rainforest to record all the hornbills? Pp. 199-212 in A. C. Kemp and M. I. Kemp, eds. The active management of hornbills and their habitats for conservation. CD-ROM. Proceedings of the $4^{\text {th }}$ International Hornbill Conference, Mabula Game Lodge, Bela-Bela, South Africa. Pretoria, South Africa: Naturalists and Nomads.

Kemp, A., Kemp, M. and Thong-aree, S. (2009). Survey of nocturnal birds at Bala rainforest, southern Thailand. Forktail 2009: 118-125.

Kinnaird, M. E., O'Brien, T. G. and Suryadi, S. (1996) Population fluctuations in Sulawesi Red-knobbed Hornbills. Tracking figs in space and time. Auk 113: 431-440.

Kinnaird, M. and O'Brien, T. (2007) Ecology and conservation of Asian hornbills. Farmers of the forest. Chicago and London: Chicago University Press.

Marsden, S. J. (1999) Estimation of parrot and hornbill densities using a point count distance sampling method. Ibis 141: 377-390.

Marsden, S. J. and Pilgrim, J. D. (2003) Factors influencing the abundance of parrots and 
hornbills in disturbed and pristine forests on New Britain, PNG. Ibis 145: 45-53.

Niyomtham, C. (2000) Flora of Hala-Bala forest. Bangkok, Thailand: Special Project Division, Royal Forest Department.

Pattanavibool, A., Poonswad, P., Jirawatkavi, N., Plongmai, K., Chimchome, V., Jornburom, P. and Chaikheiw, S. (2007) Hornbill population monitoring in tropical evergreen forest fragments in Thailand: a preliminary result. Abstract. P. 75 in A. C. Kemp and M. I. Kemp, eds. The active management of hornbills and their habitats for conservation. CD-ROM Proceedings of the $4^{\text {th }}$ International Hornbill Conference, Mabula Game Lodge, Bela-Bela, South Africa. Pretoria: Naturalists and Nomads.

Pomeroy, D. and Dranzoa, C. (1997) Methods of studying the distribution, diversity and abundance of birds in East Africa - some quantitative approaches. Afr. J. Ecol. 35: 110-123.

Poonswad, P. (1993) Current status and distribution of hornbills and their habitats in Thailand. Pp. 436-475 in P. Poonswad and A. C. Kemp, eds. Manual of the status and study of Asian hornbills. Bangkok: Hornbill Project Thailand.
Round, P. D. (1985) The current status of hornbills Bucerotidae in Thailand. Oriental Bird Club Bull. 2: 6-9.

Sivakumar, S., Singha, H. and Basnet, S. (2004) Notes on the population density and feeding ecology of the Collared Falconet Microhierax caerulescens in Buxa Tiger Reserve, West Bengal, India. Forktail 20: 97-98.

Thompson, W. L. (2002) Towards reliable bird surveys: accounting for individuals present but not detected. Auk 119: 18-25.

Thong-aree, S. (2004) List of birds recorded at Hala-Bala Wildlife Sanctuary. Bangkok: Royal Forest Department, Thailand. Unpublished report. (In Thai).

Thong-aree, S. (2007) Ecology of the Wrinkled Hornbill Aceros (Rhyticeros) corrugatus in Bala forest, southern Thailand. Pp 364-367 in A. C. Kemp and M. I. Kemp, eds. The active management of hornbills and their habitats for conservation. CD-ROM. Proceedings, $4^{\text {th }}$ International Hornbill Conference, Mabula Game Lodge, Bela-Bela, South Africa. Pretoria, South Africa: Naturalists and Nomads.

Wells, D. R. (1999) The birds of the ThaiMalay Peninsula. Vol. 1. Non-passerines. London: Academic Press.

\section{ALAN KEMP*, MEG KEMP}

Peat Swamp and Hala-Bala Rain Forest Narathiwat Province Research Unit, National Center for Genetic Engineering and Biotechnology (BIOTEC), clo Hala-Bala Wildlife Research Station, P.O. Box 3, Waeng Naratiwat, 91960, Thailand.

Current address: Naturalists and Nomads, Postnet Suite 38, Private Bag X19, Menlo Park, 0102, South Africa.

SIRIPORN THONG-AREE

Head, Hala-Bala Wildlife Research Station, Wildlife Research Division Nature Conservation Bureau, Forestry Department, Paholyothin Road, Bangkok 1090o, Thailand.

${ }^{*}$ Author for correspondence, E-mail: leadbeateri@gmail.com

Received 17 February 2010; revision accepted 21 September 2010; Published online 27 October 2011 